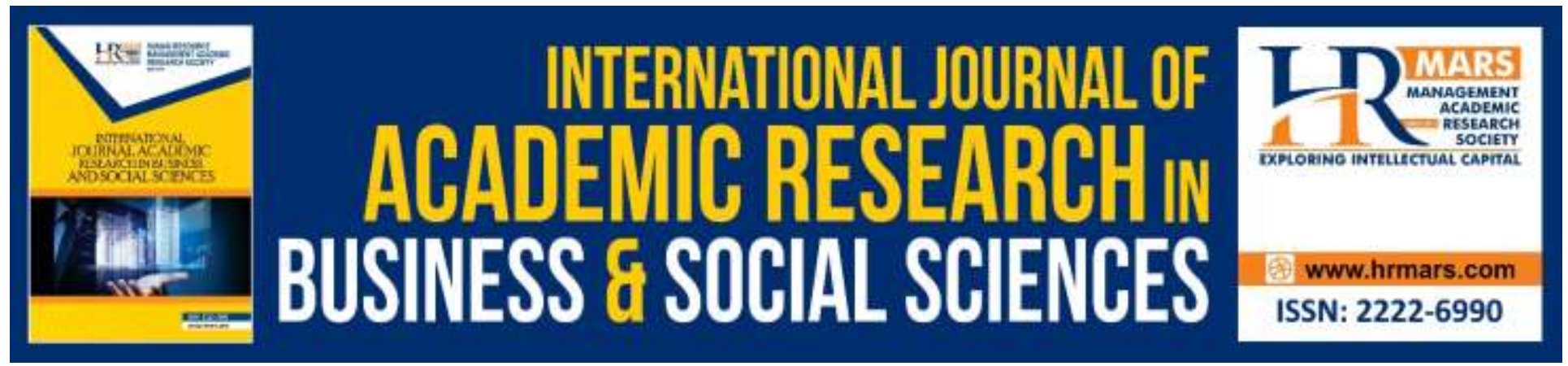

\title{
Determinants of Initial Public Offering (IPO) Underpricing in Malaysian Stock Market
}

\author{
Fong Jie Wei, Asri Marsidi
}

To Link this Article: http://dx.doi.org/10.6007/IJARBSS/v9-i11/6657

DOI: 10.6007/IJARBSS/v9-i11/6657

Received: 28 October 2019, Revised: 6 November 2019, Accepted: 13 November 2019

Published Online: 29 November 2019

In-Text Citation: (Wei, \& Marsidi, 2019)

To Cite this Article: Wei, F. J., \& Marsidi, A. (2019). Determinants of Initial Public Offering (IPO) Underpricing in Malaysian Stock Market. International Journal of Academic Research in Business and Social Sciences, 9(11), 1283-1299.

\section{Copyright: (C) 2019 The Author(s)}

Published by Human Resource Management Academic Research Society (www.hrmars.com)

This article is published under the Creative Commons Attribution (CC BY 4.0) license. Anyone may reproduce, distribute, translate and create derivative works of this article (for both commercial and non-commercial purposes), subject to full attribution to the original publication and authors. The full terms of this license may be seen at: $\underline{\text { http://creativecommons.org/licences/by/4.0/legalcode }}$

Vol. 9, No. 11, 2019, Pg. 1283 - 1299

Full Terms \& Conditions of access and use can be found at http://hrmars.com/index.php/pages/detail/publication-ethics 


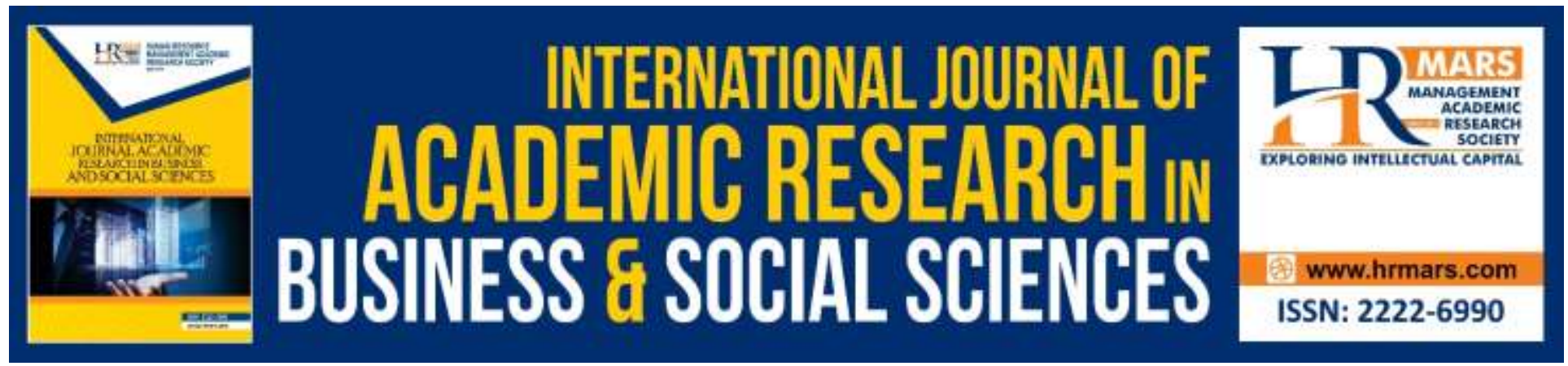

\title{
Determinants of Initial Public Offering (IPO) Underpricing in Malaysian Stock Market
}

\author{
Fong Jie Wei, Dr. Asri Marsidi \\ Faculty of Economics and Business, Universiti Malaysia Sarawak, 94300 Kota Samarahan \\ Sarawak, Malaysia \\ Email: maasri@unimas.my
}

\begin{abstract}
The primary purpose of this study is to examine the effect of issue-specific characteristics and company's attributes on the existence of underpricing of IPOs listed in Malaysia Stock Exchange from 2012 to 2015. Market-adjusted abnormal return is used as a proxy of dependent variable in this study, namely degree of IPO underpricing whereas the independent variables are the determinants of IPO. This paper aims to illustrates the relationship between the degree of IPO underpricing and the four determinants namely issues price, offer size, company age and market capitalization. Upon the analysis, the degree of IPO underpricing is $21.05 \%$ from a sample of 59 IPOs listed in the stock market. By applying multiple regression analysis, noted that market capitalization shows positive relationship with the degree of IPO underpricing whereas issues price and offer size are negatively related to the dependent variable. Moreover, the analysis indicates that the relationship between degree of IPO underpricing and company age is insignificant.
\end{abstract}

Keywords: Initial Public Offerings, Underpricing, Abnormal Return

\section{Introduction}

Several empirical studies investigated the occurrence of underpricing for IPO of newly listed firms in different countries. This universal phenomenon has been well documented by the researchers due to the public interest on the abnormal high return for the primary buyers in capital market. Most of the empirical studies used first day average return to determine the initial performance (degree of underpricing) of IPOs. According to Chong and Puah (2009), initial return of IPOs is the difference between new shares' offering price and its closing price at the end of the first trading day. A positive return is identified as underpricing whereas a negative return is recognized as overpricing (Perera, 2014; Anghelache, Anghel, Dumitrescu, Avram, 2018). 
Generally, a total of three kinds of methods that are used to identify the IPOs offering price, which are auctions, fixed priced offers and book building. The most common practice that applied around the world is book building while Malaysia applied fixed priced offers for the IPOs. For fixed priced offers method, issuers or underwriters will determine the price to be traded on the prospectus day before the shares are allocated to the investors. In order to overcome the increases of investors' demand, the IPO will allocate based on the lottery basis.

Capital market environment's differences from country to country making the comparison on the process of firm goes public become interesting. Malaysia stock market is chosen to be analyzed as Malaysia is the top tier of emerging market with stable economic growth outlook. The stock market of Malaysia, namely Bursa Malaysia is still relatively new in developing and emerging market. The stock exchange consists three main securities markets, which are Main Board, Second Board and Malaysia Exchange to securities Dealing Automated Quotation Berhad (MESDAQ). In 2009, MESDAQ was replaced by ACE market. A capitalization weighted index, Kuala Lumpur Stock Exchange Composite Index $(\mathrm{KLCl})$ is used as an indicator to oversee the stock market performance in Malaysia as a whole.

Previous studies have been conducted on the issue of IPOs underpricing in Malaysia. Those studies indicated that Malaysian capital market is vary with other emerging markets, such as unique features and regulations. Hence, this study is expected to yield some valuable insight as this research looks into the relationship of the degree of IPOs underpricing with issues price, offer size, company's age and market capitalization in the period of 2012 to 2015 in Malaysian stock market.

The rest of the paper present the literature review in Section 2, theoretical framework and hypothesis development in Section 3, research methodology in Section 4, empirical findings in Section 5 and conclusion in the last section.

\section{Literature Review}

\section{Underpricing of Initial Public Offering (IPO)}

Studies on IPOs of stock in capital market has been conducted by many researchers for the past two decades. IPO is an important financial decision for a company due to the involvement of large amount of money in the market. Underpricing of IPO is one of the common phenomena exists in stock markets.

According to Miller and Reilly (1987) and Ibbotson, Sindelar, and Ritter (1994), the price adjustment to the underpricing of IPOs can be occurred within the first listing day. The closing prices of IPO have been assumed to adjust to its intrinsic values before the end of the first trading day (Henricson, 2012). Thus, this adjustment in the short period of time seems to support Efficient Market Hypothesis (EMH), which is semi-strong form of EMH. In this degree of efficiency, 
investors can only earn above the normal returns by estimating the unpublished information or news.

Most of the scholars also used winner's curse hypothesis developed by Rock (1986) to explain IPOs underpricing. Based on Rock's explanation, informed investors known as authoritative investors will purchase or subscribe the underpriced issues. This leads to the oversubscription of IPOs and no residual issues for uninformed investors to put their order. Thus, those uninformed investors are forced to subscribe the overpriced IPOs due to the limited availability of new issues. The overpriced issues result a negative initial return for the uninformed investors although they successfully win the entire issues with an unfavorable price (Bansal \& Khanna, 2012). Due to information asymmetry, underpricing seems to benefit informed investors through insider information. Therefore, underwriters' effort in keeping the uninformed investors in the market is offer the issues with a lower market price.

In the literature of Younesi et al. (2012), lawsuit avoidance hypothesis has been used to explain the occurrence of IPOs underpricing. Law avoidance hypothesis can be described as the intention of issuers to underprice the new issues of security in order to reduce the litigation possibility by investors who are not satisfied to the security performances (Younesi et al., 2012; Kaneez \& Medha, 2018). Hughes and Thakor (1992) suggest that IPOs have been underpriced by issuers and underwriters as a form of insurance in order to reduce the likelihood and magnitude of future legal liability claims against them. In addition, Ibbotson (1975) argued that IPO issuers trust that investors will have more patience and tolerance in the offering prospectus provided that the offering is underpriced in order to avoid lawsuits.

IPO underpricing was assumed to be applied on the companies with high growth and high successful possibility. Basically, the companies underprice their securities and send a good signal to the market. Ibbotson (1975) suggests that this phenomenon will "leave a good taste in investors' mouths" because investors will be attracted by the subsequent offerings though the higher offering price. By pursuing the significance of signaling theory, empirical result from the research by Sohail and Nasr (2007) identified that market capitalization is significant towards the value of financial and non-financial firms. 
According to the hypothesis developer, Ritter (1984) states that the underpricing level of new issued share will be high if the uncertainty towards the newly listed share is high. Following by the research conducted by Loughran and Ritter (2004), they have debated that the changing risk composition of the newly listed companies can attribute to the increase of degree of underpricing. Beatty and Ritter (1986) also claimed that greater underpricing level is needed in order to attract uninformed investors to purchase or subscribe for a riskier and uncertainty on the new issue value. Furthermore, they also discovered that the existence and the necessarily of underpricing will be reduced if the occurrence of underpricing is common and there is low uncertainty on IPO's future cash flow.

Essentially, this financial phenomenon exists when the market price of the shares issued is higher than its offer price. Jones and Swaleheen (2010) defined underpricing as percentage profit of the offering price of the share by a company to closing price of shares at the end of first listing day. Majority of the previous studies showed that the initial return of IPOs is significantly positive. The researchers discovered that the degree of underpricing in the emerging market is relatively higher. For instant, Jenkinson and Ljunqvist (2001) reported that some emerging market in Asia such as Hong Kong, Malaysia and Korea showed degree of underpricing of $21.43 \%, 61.81 \%$, and $70.30 \%$ respectively.

Previous studies showed that Malaysian IPOs were underpriced in the past three decades. The first study conducted by Dowson discover the existence of underpricing in Malaysian IPO market. Dowson (1987) devoted 166.60\% degree of underpricing from 21 IPOs companies in Malaysia within the period 1978 to 1984 . Following research studied by Isa and Yong (2003) analyzed a sample of 468 companies from Malaysia in the period 1990 to 1998 find out an initial return of 94.91\%.

However, the research of Younesi, Ardekani and Hashemijoo (2012) indicates a different result compared with the previous studies that is only 7.34 percent of initial return from 66 IPOs between 2007 and 2010. This is mainly due to the global financial crisis in the period they studied, that many investors withdraw their money from the capital market to retain their capital. In Malaysia evidence, Zarafat (2013) also identified the initial performances of IPOs in the first day and the first week of listing. Their results report that during 2004 to 2007, the initial return for 166 number of IPOs on first day and first week are $8.6 \%$ and $4.2 \%$ respectively.

Prior to the work of Abu Bakar and Uzaki (2013), they found out the degree of IPO underpricing for shariah and non shariah companies in Malaysia. From their results, shariah-compliant companies had average of 36.55 percent of underpricing which is more than non shariahcompliant companies with 18.85 percent. 


\section{Determinants of IPO Underpricing}

Historically, the investigating on IPOs underpricing have focused on its determinants. Prior studies have examined the relationship between the factors that affecting the degree of underpricing. Issues price of IPOs have been listed as one of the important determinants of IPOs underpricing. The empirical evidence of Booth and Chua (1996) and Benveniste and Spindt (1989) pointed out that investors realize offering price as a proxy of uncertainty and liquidity factor to trade in secondary market. Similar result from Daily, Certo, Dalton and Roengpitya (2003) stated that higher offering prices reveal that the companies has lesser uncertainty about their future performance. The issuers are willing to provide discounts and underprice their IPOs for investors to boost the investors' confidence on the firms. Firms may set a relatively low issues price in order to increase the subscription of potential small retail investors. Thus, this will lead to an increasing demand of IPOs and the underpricing degree will spontaneously goes up.

The ex-ante risk is measured by the size of the IPO offer. According to Carter and Manaster (1990), investors may deliberate the offer size to access the initial performance of the issues besides considering the surrounding uncertainty of the IPO. Generally, larger size of IPO will be offered if the issuers is well-known firms with running years and high reputation (Slama Zouari, Boudriga and Boulila, 2011). The reduction of perceived risks of the offering assures the subscription of investors on IPO. Furthermore, in the study of Bansal and Khanna (2012), they suggest the number of shares issued has a negative relationship with the level of underpricing. These empirical studies showed the significance of the amount of raised fund in affecting the degree of underpricing in different countries.

Prior researches had listed company age as one of the proxies of ex-ante uncertainty. Adjasi et al. (2011) explained that older firms ought to exhibit lower ex ante uncertainty than younger firms. The newly created firms are less likely to be analyze by financial analysts due to the lack of historical financial reports and statements. Besides, the information asymmetry around IPOs can be reduced by firms with several operating years due to the availability of information (Hensler, Rutherford \& Springer, 1997). However, in the study of Bansal and Khanna (2012), they devoted that there is no significant relationship between the firms' age and the underpricing degree.

Moreover, investors can recognize the quality of the company through market capitalization (Boubaker \& Mezhoud, 2011). Several lines of evidences suggest that market capitalization significantly linked positively to the degree of underpricing (Bansal \& Khanna, 2012). As Bundoo (2007) claims, the bigger the companies, the greater level of underpricing. In addition, Baker and Wurgler (2007) proposes that investors are not preferred on firms that have low capitalization and unprofitable growth. Low investor sentiment causes the subscription desire on IPO decreases. Welch (1989) further argues that good firms always attempt to differentiate themselves from the poor firms by incurring a cost which these last ones cannot support. Therefore, market capitalization can be classified as one of the signals that can influence the initial performance of IPOs. 


\section{Theoretical Framework and Hypothesis Development}

In the finance literature, there are several theories of underpricing that can be used to support the variables used in this study. Prior researches used vary determinants as proxy to explain the theoretical background of the existence of underpricing. Previous researchers had tested variety of variables, including IPO characteristics in their researches. This paper used issue-specific characteristics and companies' attributes to explain the occurrence of IPOs underpricing.

Independent Variables

Dependent Variable

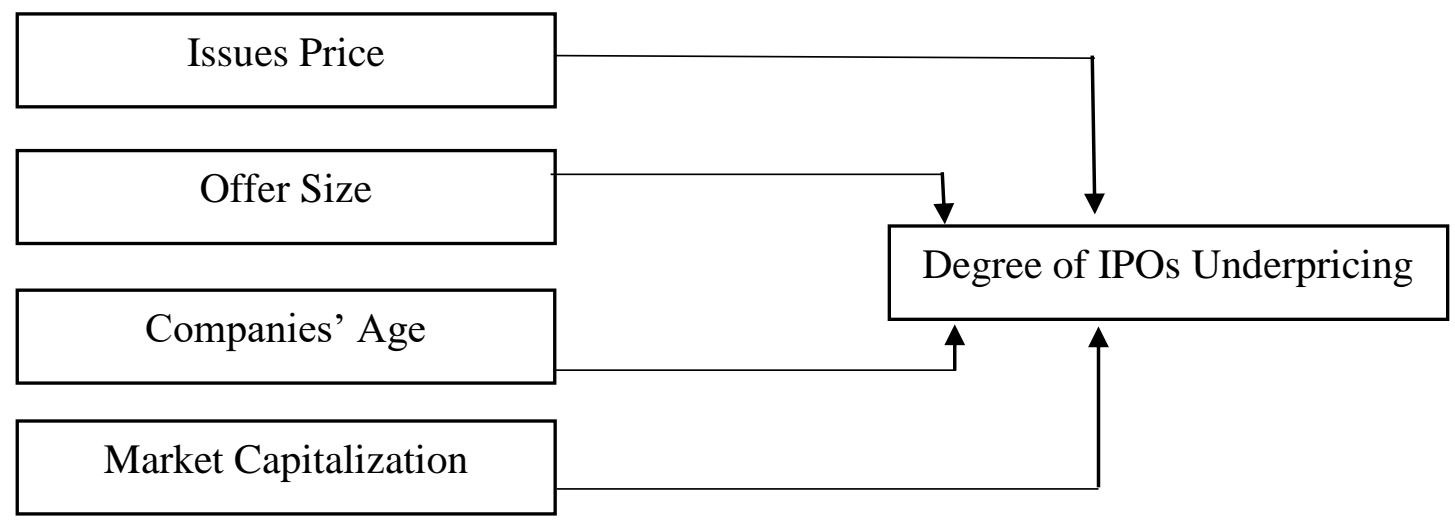

Figure 3.1 Theoretical Framework of the Study

The first theory that has been used in this study is signaling theory to explain the impact of issues price and market capitalization on the degree of underpricing. As mentioned in the literature reviews, several studies revealed that firms with a low level of issue prices will lead to a high underpricing level. The theory hypothesizes that higher-valued firms discourage lower-value firms by strategically underprice their shares to the public. In certain circumstances, firms with the more favorable prospects and larger market capitalization find it optimal to signal investors by underpricing their initial issue of shares. Thus, these positive signals catalyzed the investors' sentiment in subscribing the issues.

The second theory that can be explained to the two variables, which are offer size and companies age is uncertainty hypothesis. Investors' sentiment always uncertain before investing in any particular shares. Firms with less incorporation year will be riskier than older firms which founded in past decades in the stock market. This is due to the lack of historical financial information for analysts to look into the firm and determine the firm's financial health. Prior researchers indicated that IPOs issued by high risk firms are more underprice than the low risk firms. Further, if a firm has outstanding financial performance and offers large volume of issues in the market, it is easier to persuade investors to subscribe the IPO with less uncertainty. 
INTERNATIONAL JOURNAL OF ACADEMIC RESEARCH IN BUSINESS AND SOCIAL SCIENCES

Vol. 9, No. 11, November, 2019, E-ISSN: 2222-6990 ㄷ 2019 HRMARS

In order to test the significant relationship between the variables, hypothesis testing has to be conducted. Based on the literature, the followings are the hypotheses proposed in this study:

$\mathbf{H}_{1}$ : There is a relationship between degree of IPO underpricing and issues price in Malaysia Stock Exchange.

$\mathbf{H}_{\mathbf{2}}$ : There is a relationship between degree of IPO underpricing and offer size in Malaysia Stock Exchange.

$\mathbf{H}_{3}$ : There is a relationship between degree of IPO underpricing and company age in Malaysia Stock Exchange.

$\mathbf{H}_{4}$ : There is a relationship between degree of IPO underpricing and market capitalization in Malaysia Stock Exchange.

\section{Research Methodology}

\section{Sample Selection and Data}

The sample employed in this study consists of 59 listed IPOs on Main Market and ACE market in Malaysia Stock Exchange from January 1, 2012 to December 1, 2015. The secondary source of data are mainly collected from Bursa Malaysia website, Bursa Station Professional analysis software, DataStream Advance from the Thomson Reuters Company, The Star Online and prospectus of the companies. As a result, there are 16 percent of the IPOs are listed at ACE market, while the others are listed on Main Market. The selected companies are also covered various industries in Malaysia to avoid biasness on certain industry.

Table 3.1: Distribution of IPO in Two Different Markets, 2012-2015

\begin{tabular}{cccc}
\hline Year & Main Market & ACE Market & Total \\
\hline 2012 & 15 & 2 & 17 \\
2013 & 16 & 1 & 17 \\
2014 & 11 & 3 & 14 \\
2015 & 7 & 4 & 11 \\
Total & 49 & 10 & 59 \\
\hline
\end{tabular}

Source: Bursa Malaysia Berhad (2016)

Table 3.1 exhibits the data sample of the going public firms on Malaysia Stock Exchange in the time period of January 2012 until December 2015. The data have been distributed into two categories, which are Main Market and ACE market. There is a total of 49 out of 59 listed companies had issued their IPO in the Main Market.

\section{Empirical Methodology}

The study uses the data of 59 IPO companies listed on both main market and ACE market in Malaysian IPO market from January 2012 to December 2015. The analytical software that was used for empirical findings is STATA version 12. The method used for results findings includes descriptive statistics, Pearson's correlation and multiple regression analysis. In order to analyze 
degree of IPOs underpricing in first day trading at Malaysia Stock Exchange, the equation below is used:

$$
R_{i_{1}}=\frac{C P_{i_{1}}-O F_{i_{0}}}{O F_{i_{0}}} \times 100 \%
$$

where $R_{i_{1}}$ is the raw first day return on the IPO, known as the underpricing degree of IPO in firm $i, C P_{i_{1}}$ is closing price in firm $i$ and $O F_{i_{0}}$ is the offering price in firm $i$. Therefore, the IPO return on first day of listing can be determined by subtracting offering price of the IPO from the closing price on the first trading day, divided by the offering price.

In order to identify the changes in market return, the return on market index during the same period can be measured as follows:

$$
R_{m_{1}}=\frac{P_{m_{1}}-P_{m_{0}}}{P_{m_{0}}} \times 100 \%
$$

where $P_{m_{1}}$ is the closing market index value on first trading day, $P_{m_{0}}$ is the closing market index value on the last day of subscription period of the IPO, and $R_{m_{1}}$ is the first day's comparable market return. In this study, Kuala Lumpur Composite Index $(\mathrm{KLCl})$ is used (the market capitalization weighted index for the KLSE) as a proxy for the market index.

In order to explain for the effect of the substantial delay between pricing and listing, the degree of underpricing is measured as the market-adjusted abnormal return (MAR) for each IPO on the first listing day and it is computed as:

$$
M A R_{m_{1}}=R_{i_{1}}-R_{m_{1}}
$$

\section{Explanatory Variables and Model}

Several hypotheses explained the possible determinants for the initial return of IPO. Based on previous empirical research, four explanatory variables have been selected to test the correlation between the variables used and identify the actual factors that influence the level of underpricing in Malaysia stock market.

The dependent variable which is the degree of IPOs underpricing can be explained by the following factors included issues price, offer size, companies' age and market capitalization. These explanatory variables are expected to impact the underpricing level of IPO.

Issues price measure the degree of underpricing related to the first price offered within trading price periods as defined in Bursa Malaysia. The issue price is the first price given for IPO's share 
during the first trading period and associate it to the closing price at the very end of the same period.

The second explanatory variable is offer size of IPO. According to Ibbotson et al. (1994), offer size can be measured by the number of offered shares multiplied by the offer price. Whereas for the variable of company's age, it is computed from the year of incorporation to the year of IPOs listed at KLSE. The last independent variable tested is market capitalization, which is a proxy of company size that calculated by the total number of shares multiplied by the closing market price per share of listing date.

Multiple regression is used to examine whether the aforesaid variables can explicate the existence of IPO underpricing in Malaysia stock market. The model is described as follow:

$$
M A R_{i}=\beta_{0}+\beta_{1}\left(I P_{i}\right)+\beta_{2}\left(O S_{i}\right)+\beta_{3}\left(A G E_{i}\right)+\beta_{4}\left(M C A P_{i}\right)+\varepsilon_{i}
$$

where,

$\begin{array}{ll}M A R_{i} & : \text { Market-adjusted abnormal return } \\ I P_{i} & : \text { Issues price } \\ O S_{i} & : \text { Offer size } \\ A G E_{i} & : \text { Company age } \\ M C A P_{i} & : \text { Market capitalization } \\ \varepsilon_{i} & : \text { Error terms }\end{array}$

\section{Empirical Results and Findings}

Table 4.1: Descriptive statistics for variables, 2012-2015

\begin{tabular}{lccccc}
\hline \multicolumn{1}{c}{ Variable } & Observation & Minimum & Maximum & Mean & Std. Deviation \\
\hline MAR (\%) & 59 & -25.47 & 315.04 & 21.05525 & 49.35012 \\
IP & 59 & 0.12 & 4.55 & 1.13 & 0.8571867 \\
OS & 59 & 2750000 & $1.00 \mathrm{e}+10$ & $4.53 \mathrm{e}+08$ & $1.34 \mathrm{e}+09$ \\
AGE (Years) & 59 & 1 & 68 & 6.067797 & 10.53707 \\
MCAP & 59 & 3795000 & $1.05 \mathrm{e}+10$ & $5.02 \mathrm{e}+08$ & $1.45 \mathrm{e}+09$ \\
\hline
\end{tabular}

Notes: MAR= Market-adjusted abnormal return, IP= Issue price, OS= Offer size, AGE= Company age, MCAP $=$ Market capitalization.

Table 4.1 illustrates the descriptive statistics of the dependent and independent variables. A sample of 59 observations in the study have been analyzed. The mean of market-adjusted abnormal return is 21.05, which means that the average degree of underpricing in Malaysia IPO market is $21.05 \%$, with a deviation of $49.35 \%$ from the mean of underpricing. The maximum and minimum of underpricing degree recorded 315.04 and -25.47 respectively. 
The independent variable, issue price (IP) has a range from RM 0.12 to RM 4.55. The data shows that lower issue price will lead the issuer to offer higher number of shares to the market. For offer size (OS), it indicates that the IPOs have a mean of offer size amounted to RM 453 million. On top of that, the average company age is 6 years among the sample that have been analyzed. The minimum age and the maximum age for the companies to be listed in Malaysia Stock Exchange in the research period is 1 year and 68 years respectively. For market capitalization (MCAP), the mean statistically records at RM502 million.

Table 4.2: Degree of underpricing in Malaysia Stock Market based on sector, 2012-2015

\begin{tabular}{lccccc}
\hline \multicolumn{1}{c}{ Sector } & Observation & Mean & Std. Dev. & Min. & Max. \\
\hline Construction & 4 & 19.58 & 21.03705 & 1.01 & 44.01 \\
Consumer Products & 5 & 29.58 & 8.856001 & 15.97 & 38.41 \\
Finance & 3 & 8.08666 & 25.47976 & -10.96 & 37.03 \\
Industrial Products & 8 & 7.54625 & 14.5257 & -14.15 & 26.81 \\
Plantation & 3 & 24.02667 & 28.14156 & 1.26 & 55.49 \\
Properties & 4 & 24.8025 & 37.68892 & -7.33 & 79.26 \\
REITs & 2 & 10.35 & 3.804235 & 7.66 & 13.04 \\
SPAC & 3 & -19.99333 & 7.433339 & -25.47 & -11.53 \\
Technology & 3 & 17.84667 & 17.98579 & 4.5 & 38.3 \\
Trading and Services & 24 & 31.0775 & 72.2544 & -23.49 & 315.04 \\
\hline
\end{tabular}

Notes: REITs= Real Estate Investment Trusts, SPAC= Special Purpose Acquisition Company

Table 4.2 shows the degree of underpricing in Malaysia IPO market based on sector from 2012 to 2015. From the sample of 59 IPOs, there are 24 IPOs from the companies of trading and services sector. The mean of degree of IPO underpricing is the highest among the sectors, which is $31.0775 \%$. The mean of the market-adjusted abnormal return is the highest among all of the sector analyzed. For consumer products sector, the sample recorded five companies with a mean of $29.58 \%$ of underpricing, with highest minimum return of $15.97 \%$ across the all of the sectors. As such, investors had guaranteed their capital on the IPOs in consumer product sector due to the stronger initial performance as compared with the other sectors. Noted that investors also earned lucrative returns on IPO in properties sector in the period of 2012 to 2015. The average return in properties sector maintained at $24.02 \%$ across the four years.

By running the test of Pearson's Correlation, it can be observed that all of the four independent variables are negatively correlated towards the dependent variable as evidenced in the table below:

Table 4.3: Pearson's Correlation between dependent variable and independent variables

MAR IP OS AGE MCAP 


\begin{tabular}{c|ccccc}
\hline MAR & 1.0000 & & & & \\
& & & & & \\
IP & -0.2018 & 1.0000 & & & \\
& $(0.1254)$ & & & & \\
OS & -0.0714 & $0.2971^{* *}$ & 1.0000 & & \\
& $(0.5912)$ & $(0.0223)$ & & & \\
AGE & -0.0936 & 0.1693 & -0.0309 & 1.0000 & \\
& $(0.4809)$ & $(0.1998)$ & $(0.8163)$ & & \\
MCAP & -0.0360 & 0.3113 & $0.9913^{* * *}$ & -0.0415 & 1.0000 \\
& $(0.7867)$ & $(0.0164)$ & $(0.0000)$ & $(0.7549)$ &
\end{tabular}

Notes: $\mathrm{MAR}=$ Market-adjusted abnormal return, IP= Issue price, OS= Offer size, AGE= Company age, MCAP $=$ Market capitalization, Asterisk $\left({ }^{* *}\right)$ means $p<0.05$ and statistically significant at 5 percent significance level, Asterisk $\left({ }^{* * *}\right)$ means $p<0.01$ and statistically significant at 1 percent significance level.

Noted that the correlation coefficients between independents variable and dependent variable are all presented in negative values which explained the negative relationship between the explanatory variables and the degree of IPO underpricing. The correlation coefficients of all predictors of market-adjusted abnormal return (MAR) is uniformly lied in the range of 0.01 to 0.30 as the relationships between two variables are pretty weak.

The degree of collinearity between issue price (IP) and market-adjusted abnormal return is 0.2018 , means that issue price has a weak negative linear relationship with MAR. The result is similar with the research conducted by Ibbotson et al. (1994). The explanation for the relationship is lower issue price set by the issuer in order to encourage and give opportunity for small retail investors to subscript the IPO. This will lead to a high demand for IPO subscription, thus results in higher degree of underpricing. For the correlation matrix between offer size (OS) and MAR, the correlation coefficient between the two variables is -0.0714 . This implied that offer size of IPO has a weak inverse relationship with market-adjusted abnormal return. Therefore, offer size of IPO is negatively associated with IPO underpricing level. The outcome relationship between the two variables is similar with the previous studies conducted by Agathee et al. (2002) and Bansal and Khanna (2012). Based on their empirical results, they substantiated that issues offered has significant negative relationship with the degree of underpricing.

The third independent variable, company age (AGE) is negatively associated towards the degree of underpricing with correlation coefficient of 0.0936 , which consider weak collinearity. Several researchers found that there is an inverse relationship between the age of firm and underpricing 
level that can be explained by lack of financial information on newly created companies. This will systematically lead to a higher ex ante uncertainty, thus causes the degree of underpricing reaches to another higher level. Moreover, the result shows that market capitalization (MCAP) is negatively correlated to the degree of underpricing. The research conducted by Falck (2013) represented that the higher the market capitalization, the lower the uncertainty which can lead the degree of underpricing to decrease. Therefore, the result matches the study of Falck where market capitalization is negatively correlated to underpricing degree of IPO. However, according to Baker and Wurgler (2007), investors will assume that low capitalization companies have poor profitability and growth rate, which will lead the demand of IPO subscription become lower.

Table 4.6: Multiple Regression Analysis of the Model

\begin{tabular}{cccclcl}
\hline MAR & Coef. & Std. Err. & $\mathrm{t}$ & $\mathrm{P}>|\mathrm{t}|$ & \multicolumn{2}{c}{ [95\% Conf. Interval] } \\
\hline IP & -.134071 & -.0789776 & -1.70 & $0.095^{*}$ & -.2924115 & .0242695 \\
OS & -.0008042 & .0003574 & -2.25 & $0.029^{* *}$ & -.0015207 & -.000876 \\
AGE & -.0014141 & .0061034 & -0.23 & 0.818 & -.0136506 & .0108225 \\
MCAP & .0007515 & .0003336 & 2.25 & $0.028^{* *}$ & .0000827 & .0014203 \\
constant & .3574547 & .1059673 & 3.37 & $0.001^{* * *}$ & .145003 & .5699064 \\
\hline
\end{tabular}

Notes: MAR= Market-adjusted abnormal return, IP= Issue price, OS= Offer size, AGE= Company age, $\mathrm{MCAP}=$ Market capitalization, Asterisk $\left({ }^{* * *}\right)$ means $\mathrm{p}<0.01$ and statistically significant at 1 percent significance level, Asterisk $\left({ }^{* *}\right)$ means $p<0.05$ and statistically significant at 5 percent significance level, Asterisk $\left({ }^{*}\right)$ means $p<0.1$ and statistically significant at 10 percent significance level.

The table above shows the multiple regression analysis for the study. The coefficient of determination, $\mathrm{R}^{2}$ in the analysis is 0.1267 which indicates that $12.67 \%$ of the variation of dependent variable around the mean are explained by the independent variables. In order to determine whether the determining variables have significant impacts in the dependent variable, $p$-value is needed to be observed. From the analysis, all of the explanatory variables are significant except for AGE variable ( $p$-value=0.818). Thus, the result rejects the hypothesis, $\mathrm{H}_{3}$. Therefore, there is no relationship between company age and degree of underpricing.

For the other determining variables such as offer size (OS) and market capitalization (MCAP), they significant at $5 \%$ level of significance, with $p$-values recorded 0.029 and 0.028 respectively. Besides, issue price of IPO also has an impact towards the IPO underpricing level, which significant at $10 \%$ level of significance. Noted that the smallest coefficient variable is market capitalization, recorded 0.0007515 , with a standard error of 0.0003336 which indicates that the variable has a very weak positive relationship towards the proxy of underpricing level. The result is against to the result shows in the Pearson Correlation Coefficient. The explanation for the difference of result is the relationships are parametrized by a statistical model in the multiple regression analysis. This will lead to a more complete quantitative description of the correlation. 
Hence, the outcome for market capitalization towards degree of IPO underpricing is consistent the results from Bundoo (2007) and Bansal and Khanna (2012).

In contrast, the largest value of coefficient in Table 4.3 belongs to issue price, which is -0.134071 . It states that issue price of IPO in Malaysia during 2012 to 2015 has a weak negative association to the degree of underpricing. The negative relationship can be explained by investors act issue price as a proxy of firm's confidence in their future performance. A company with low IPO issue price indicates that the company is uncertain on the future growth which consider risky. It might increase the demand of subscription from speculation investors, thus push the degree of underpricing to a higher level.

For offer size, the coefficient shows -0.0008042 , with its corresponding $p$-value of 0.029 which is relatively weak. The outcome from the analysis is similar with the research done by Agathee et al. (2002). The negative correlation of offer size towards degree of underpricing can be clarified by uncertainty hypothesis. From the result, Malaysian investors unclear and afraid on the companies which offering lesser shares in the IPO market. According to Beatty and Ritter (1986), uninformed investors tends to buy those uncertain IPOs since they speculate for a higher degree of underpricing. Therefore, the lower the offer size, the higher the IPO underpricing level.

Overall, the final regression model for this study is presented below:

$$
\begin{gathered}
M A R_{i}=-0.134071\left(I P_{i}\right)^{*}-0.0008042\left(O S_{i}\right)^{* *}-0.0014141\left(A G E_{i}\right) \\
+0.0007515\left(M C A P_{i}\right)^{* *}+0.3574547
\end{gathered}
$$

Notes: Asterisk $\left({ }^{* *}\right)$ means $\mathrm{p}<0.05$ and statistically significant at 5 percent significance level, Asterisk $\left({ }^{*}\right)$ means $p<0.1$ and statistically significant at 10 percent significance level.

From the model, it can be seen that offer size (OS) and market capitalization (MCAP) are significant to degree of underpricing at $5 \%$ significance level whereas issue price (IP) is significant at $10 \%$ level of significance. The only explanatory variable that is statistically insignificant to the dependent variable is company age (AGE). Hence, the hypotheses for issue price $\left(\mathrm{H}_{1}\right)$, offer size $\left(\mathrm{H}_{2}\right)$ and market capitalization $\left(\mathrm{H}_{4}\right)$ are not rejected. Since age of company do not affect degree of underpricing in Malaysian IPO market, the hypothesis $\left(\mathrm{H}_{3}\right)$ is rejected.

By analyzing the coefficient of the determining variables, it can be explained that when IP increase by 1 percent, MAR will decrease by 0.1340 percent. Besides, when OS increase by 1 percent, MAR will decrease by 0.0008 percent. Moreover, when company age increase by 1 unit, MAR increase by 0.0014 percent. Lastly, for every 1 percent increase of MCAP, MAR will increase by 0.0007 percent. The constant of the model is 0.3574 . 


\section{Conclusion}

The findings of the study have shown that offer size, market capitalization and issue price have significant impacts on the IPO under pricing level whereas company age is not statistically significant towards the degree of IPO under pricing. Therefore, the hypothesis of company age (i.e. $\mathrm{H}_{3}$ ) has to be rejected while the other hypotheses are accepted. Such results reflect that the company age has no effect on the IPOs under pricing level in the Malaysian stock market.

The negative relationship between offer size and the degree of underpricing implied that higher offer size can reduce the ex-ante uncertainty on the newly listed firm among Malaysian investors. If the uncertainties have been reduced, the price of IPO will be less volatile. The investors always assume that companies which offered large size of IPO will have more guarantee towards their future financial performance. Therefore, issuers are encouraged to offer larger size to the investors, not only stabilize the IPO price, but also raising more funds for company development.

For market capitalization, the variable is found to be positively correlated to the underpricing degree. The results can be interpreted as the smaller size of company (smaller market capitalization), the lower degree of underpricing in KLSE during 2012 to 2015 . Generally, greater companies have greater reputation to have a higher audit quality. Therefore, larger firms tend to bear more volatile share price. However, with higher degree of underpricing, this will certainly increase the risks faced by both issuer and buyer.

The study contributes to the theoretical and contextual settings of the IPOs underpricing in the Malaysian stock market by suggesting several significant factors to be considered prior to the issuance of IPOs such as offer size, market capitalization as well as issue price. As such, by knowing and understanding these factors, the related and respected companies may take the necessary and relevant strategies to overcome the issues of IPOs underpricing.

In the future, the researchers should attempt to examine other relevant variables or factors that may have the possibilities to influence the degree of underpricing apart from the ex-ante uncertainty factors by focusing on the other countries in the Southeast Asia region. The possible reasons to focus on other Southeast Asia countries are because of the growth of debt and the equity market for raising the funds.

\section{References}

Adjasi, C. K., Osei, K. A., \& Fiawoyife, E. U. (2011). Explaining underpricing of IPOs in frontier markets: Evidence from the Nigeria Stock Exchange. Research in International Business and Finance, 25(3), 255-265.

Agathee, U. S., Sannassee, R. V., \& Brooks, C. (2002). The underpricing of IPOs on the Stock Exchange of Mauritius. Research in International Business and Finance, 26(2), 281-303. 
Anghelache, C., Anghel, M.G., Dumitrescu, D., Avram, D. (2018). Romania's Strategy in the Field of Research and Innovation, in the Context of the European Union, International Journal of Academic Research in Accounting, Finance and Management Sciences 8 (2): 95-101.

Bakara, N. B. A., \& Uzakib, K. (2013). An empirical study of initial public offerings underpricing for shariah-compliant companies: the case of Malaysian market. International Journal of Economics, Business and Finance. Vol. 1, No. 9, October, PP: 262 - 274.

Baker, M., \& Wurgler, J. (2007). Investor sentiment in the stock market. The Journal of Economic Perspectives, 21(2), 129-151.

Bansal, R., \& Khanna, A. (2012). Determinants of IPOs Initial Return: Extreme Analysis of Indian Market. Journal of Financial Risk Management, 1(04), 68.

Beatty, R. P., \& Ritter, J. R. (1986). Investment banking, reputation, and the underpricing of initial public offerings. Journal of financial economics, 15(1), 213-232.

Benveniste, L. M., \& Spindt, P. A. (1989). How investment bankers determine the offer price and allocation of new issues. Journal of financial Economics, 24(2), 343-361.

Booth, J. R., \& Chua, L. (1996). Ownership dispersion, costly information, and IPO underpricing. Journal of Financial Economics, 41(2), 291-310.

Boubaker, A., \& Mezhoud, M. (2011). Impact of managerial ownership on operational performance of IPO firms: French context. International Journal of Management Science and Engineering Management, 6(3), 191-197.

Bundoo, S. K. (2007). An analysis of IPOs underpricing in Mauritius. African Journal of Accounting, Economics, Finance and Banking Research, 1(1).

Bursa Malaysia Berhad. (2016). Listing Statistics. Retrieved from http://www.bursamalaysia.com/market/listed-companies/initial-public-offerings/listingstatistics/

Carter, R., \& Manaster, S. (1990). Initial public offerings and underwriter reputation. The Journal of Finance, 45(4), 1045-1067.

Chong, F., \& Puah, C. H. (2009). The Malaysian IPO market: Volume, initial returns and economic conditions. International Review of Business Research Papers, 5(5), 182-192.

Daily, C. M., Certo, S. T., Dalton, D. R., \& Roengpitya, R. (2003). IPO underpricing: A meta-analysis and research synthesis. Entrepreneurship Theory and Practice, 27(3), 271-295.

Dawson, S. M. (1987). Secondary stock market performance of initial public offers, Hong Kong, Singapore and Malaysia: 1978-1984. Journal of Business Finance \& Accounting, 14(1), 6576.

Falck, F. (2013). Underpricing of Norwegian IPOs: Empirical testing of selected underpricing theories on the Oslo Stock Exchange from 2003 to 2012. Master thesis. Applied Economics and Finance. Copenhagen Business School.

Henricson, T. (2012). Underpricing in the Swedish IPO market: Can investors earn abnormal returns by investing in IPOs. Master's Thesis. Jönköping International Business School.

Hensler, D. A., Rutherford, R. C., \& Springer, T. M. (1997). The survival of initial public offerings in the aftermarket. Journal of Financial Research, 20(1), 93-110. 
Hughes, P. J., \& Thakor, A. V. (1992). Litigation risk, intermediation, and the underpricing of initial public offerings. Review of financial studies, 5(4), 709-742.

Ibbotson, R. G. (1975). Price performance of common stock new issues. Journal of financial economics, 2(3), 235-272.

Ibbotson, R. G., Sindelar, J. L., \& Ritter, J. R. (1994). The market's problems with the pricing of initial public offerings. Journal of applied corporate finance, $7(1), 66-74$.

Jenkinson, T., \& Ljungqvist, A. (2001). Going public: The theory and evidence on how companies raise equity finance. Oxford University Press on Demand.

Jones, T. L., \& Swaleheen, U. M. (2010). Endogenous examination of underwriter reputation and IPO returns. Managerial Finance, 36(4), 284-293.

Kaneez, B.-S., \& Medha, K. (2018). Factors Influencing Grade 10 Students' Career Choice in Mauritius. International Journal of Academic Research in Progressive Education and Development, 7(2), 30-44.

Loughran, T., \& Ritter, J. (2004), 'Why has IPO underpricing changed over time?', Financial Management, 33(3), 5-37.

Miller, R. E., \& Reilly, F. K. (1987). An examination of mispricing, returns, and uncertainty for initial public offerings. Financial Management, 33-38.

Perera, K. L. W. (2014). Evaluation of Market Performance of Initial Public Offerings (IPOs) and Its Determinants: Evidence from Australian IPOs (Doctoral dissertation, Victoria University).

Ritter, J. R. (1984). The" hot issue" market of 1980. Journal of Business, 215-240.

Rock, K. (1986). Why new issues are underpriced. Journal of financial economics, 15(1-2), 187212.

Sohail, M. K., \& Nasr, M. (2007). Performance of initial public offerings in Pakistan. International Review of Business Research Papers, 3(2), 420-441.

Welch, I. (1989). Seasoned offerings, imitation costs, and the underpricing of initial public offerings. The Journal of Finance, 44(2), 421-449.

Younesi, N., Mahdavi-Ardekani, A., \& Hashemijoo, M. (2012). Performance of Malaysian IPOs and impact of return determinants. Journal of Business Studies Quarterly, 4(2), 140-158.

Zarafat, H. (2013). Performance of initial public offerings: an empirical study. International Journal of Finance, 25(4), 8012-8034.

Zouari, S. B., Boudriga, A., \& Boulila, N. T. (2011). Determinants of IPO underpricing: Evidence from Tunisia. The International Journal of Business and Finance Research, 5(1), 13-32. 